\title{
Study of Online Teaching with Rain-Class during COVID-19 Period
}

\author{
Xichen Lin $^{1, *}$ and Xinjian Zhang ${ }^{1}$ \\ ${ }^{1}$ Department of Mechanical and Electrical Engineering, Wenhua College, Wuhan 430073, China \\ *Corresponding author. Email: westlifelxc@163.com
}

\begin{abstract}
Under the situation of COVID-19, Chinese students, especially in Wuhan, have to stay in isolation for a long time. To ensure students could continue their study works and receive a good education at home, teachers need to try their best to give lessons online. This article states online teaching experience with the Rain-Class platform in the epidemic period. The difference in teaching method and lesson design between traditional and online education as well as problems and influence are studied. Data of a questionnaire of online teaching was also included. Teachers should improve their teaching behaviour based on reflective pedagogical thinking in this period.
\end{abstract}

Keywords: COVID-19, online teaching, rain-class, teaching reflection, course design

\section{INTRODUCTION}

During epidemic prevention and control period in the first half of 2020, almost all Chinese students have to keep away from universities and colleagues. Teachers need to give instructions on network platforms. Although online education has become a usual method, it's still difficult for teachers to prepare all lessons for only online teaching in such a short time [1], [2]. Universities and colleges should learn from this incident, whose teachers need to improve their teaching method, tool and platform with developed information technology [3].

Rain-Class, produced by Tsinghua University, is a network teaching platform that combines Power-Point and WeChat. Teachers could push their MOOC, courseware, videos, exercises and exams through it to students' smart phone and computer, communicate with students and get related statistics to improve teaching [4].

\section{INSTRUCTIONAL MODEL}

\subsection{Combined Instructional Model}

In recent years, before the home isolation from COVID-19, teaching in Rain-Class platform has been already become a widely used instructional model.

Present teaching design could be divided into 4 parts: students' preparation, classroom teaching, interaction course and homework. Some teachers prefer a combined instruction model that traditional classroom teaching and Rain-Class teaching supplement and complement each other, such as ones compared in table 1 to table 4 below [5].

Table 1. Students’ preparation

\begin{tabular}{|c|c|c|}
\hline Teachers & Traditional Classroom & Rain-Class \\
\hline Inform contents & Knowledge points in textbooks or on the internet & Video, document, exercise and question \\
\hline Inform ways & Oral or written in the class & On the online platform \\
\hline Check & Communication or interaction in the next class & Students' online reply before the next class \\
\hline Purpose & To help students learn more easily & To adjust the teaching plan with reply \\
\hline
\end{tabular}


Table 2. Classroom teaching

\begin{tabular}{|c|c|c|}
\hline Teachers & Traditional Classroom & Rain-Class \\
\hline Teaching methods & $\begin{array}{l}\text { Problem orientated, flipped classroom, physical } \\
\text { display, video explanation, case analysis }\end{array}$ & $\begin{array}{l}\text { Choice question, subjective item, fill-in-the- } \\
\text { blanks, and vote (by scan QR code) }\end{array}$ \\
\hline Check & Some random or typical students' reply & Everyone's answer \\
\hline Consider & $\begin{array}{l}\text { How much they learn? } \\
\text { How about the effect? } \\
\text { Are they interested in? }\end{array}$ & $\begin{array}{l}\text { How many students have mastered and how } \\
\text { many ones confused? }\end{array}$ \\
\hline Purpose & $\begin{array}{l}\text { To adjust the teaching rhythm that students could } \\
\text { keep up with teacher }\end{array}$ & $\begin{array}{l}\text { To promote each student to actively } \\
\text { participate in class }\end{array}$ \\
\hline
\end{tabular}

Table 3. Interaction course

\begin{tabular}{|c|c|c|}
\hline Teachers & Traditional Classroom & Rain-Class \\
\hline $\begin{array}{c}\text { Interaction } \\
\text { methods }\end{array}$ & $\begin{array}{c}\text { Problems, } \\
\text { group discussion, } \\
\text { case analysis, } \\
\text { material practice, } \\
\text { student as host of class }\end{array}$ & $\begin{array}{c}\text { Exercises and answer statistics } \\
\text { automatically created by platform }\end{array}$ \\
\hline Target & Few typical students & All students \\
\hline Check & Students' representation & $\begin{array}{c}\text { Expression, accuracy, mastery, and } \\
\text { difficult point }\end{array}$ \\
\hline Purpose & $\begin{array}{r}\text { To create a lively atmosphere in the class for students } \\
\text { interested in learning motivation }\end{array}$ & $\begin{array}{c}\text { To understand the overall learning } \\
\text { situation }\end{array}$ \\
\hline
\end{tabular}

Table 4. Homework

\begin{tabular}{|c|c|c|}
\hline Teachers & Traditional Classroom & Rain-Class \\
\hline Contents & $\begin{array}{c}\text { Exercise, discussion, video, questionnaire, text, short } \\
\text { essay }\end{array}$ & Exercise and exam with multimedia resources \\
\hline Interflow & Online or offline & On platform \\
\hline $\begin{array}{c}\text { Check } \\
\text { time }\end{array}$ & Usually in the next class & Online before next class \\
\hline Statistics & Teachers study and analysis data themselves & $\begin{array}{c}\text { The platform helps them create data, table and } \\
\text { graph. }\end{array}$ \\
\hline
\end{tabular}

Generally, these two teaching methods complement each other and promote together. In class, teachers understand students' learning conditions by both visual observation and communication like question and discussion. Teachers could find students' confused content much more easily and focus on key points [6].

After targeted and tendentious questions, documents, videos and other related material are added in library on the Rain-Class platform, teachers could semi compulsorily lead students to join in the interaction course. Everyone should use their smart phone to login in and deal with materials uploaded, instead of desert in class. The data statistics of students' answer and reply enable teachers to understand their class more.
As shown in Figure 1, it can be concluded that Rain-Class is a deep utilization in limited 90 minutes rather than replace traditional classroom teaching. Compared with the one to one communication, Rain-Class provides a one to all communication as well as a real-time and exact comprehensive collection of teaching effects. Besides, it's much easier for teachers to obtain all students' feedback and feeling from network platform than face to face talking, while many students in this age are sometimes a little "shy" and not willing to make an answer in class [7]. Also question, discussion, vote that everyone takes part in and the comparison or explanation of reply could arouse students' interest in some degree. Although these two teaching methods have obvious differences, they could both help teachers to teach well in different ways [8]. 


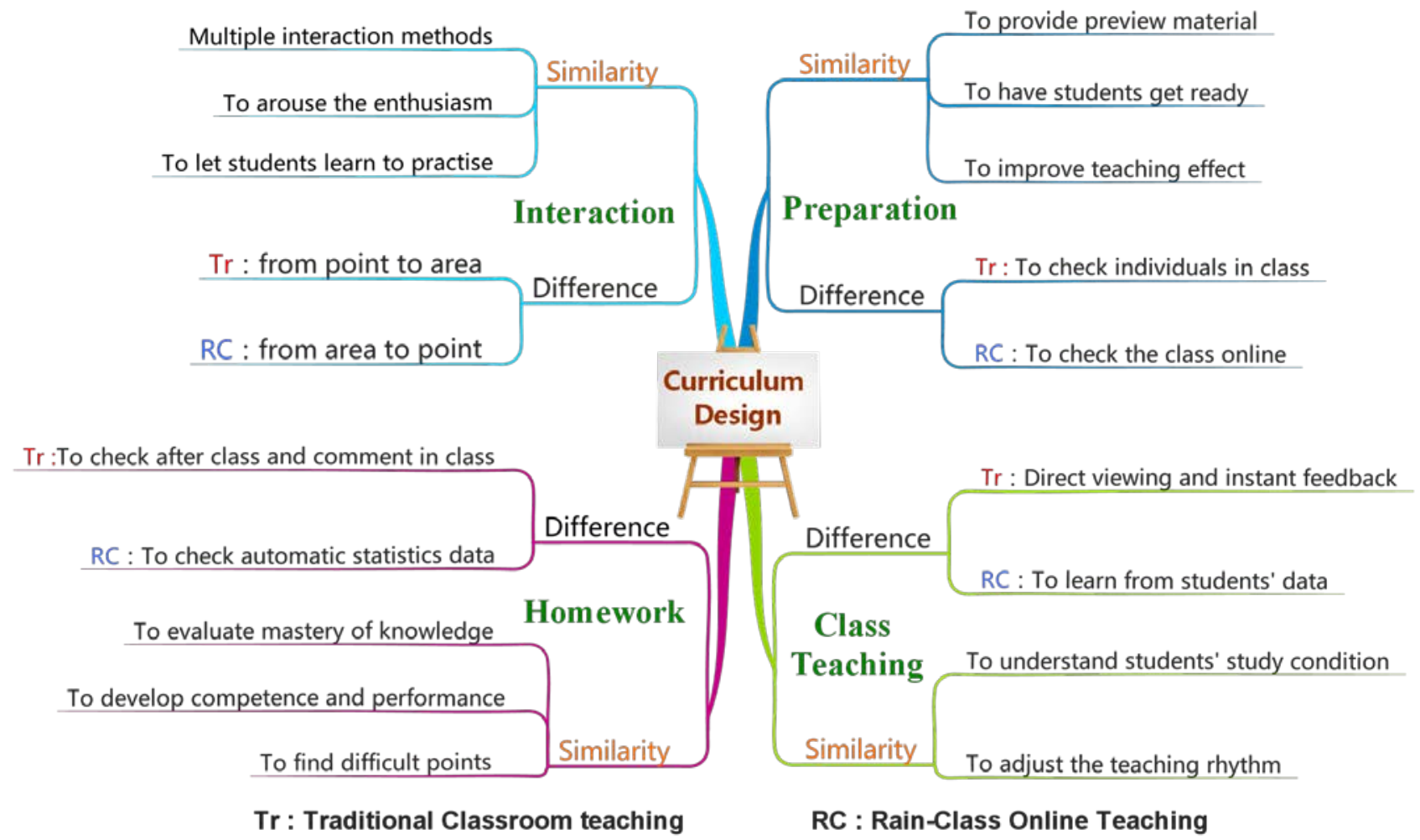

Figure 1. Similarities and differences between traditional and Rain-Class teaching

\subsection{Only Rain-Class Instruction Model}

During the COVID-19 period, both teachers and students have to stay in isolation. It's a huge challenge for both teachers and students because they could only continue their courses online like in Rain-Class, instead of the combined course mentioned before. There are a lot of problems in the online course at every point, which comes from not only teaching and study but also unexpected conditions.

A complex questionnaire of feedback and suggestion about online course in the first month (from 2020.2.24 to 2020.3.22) of the term was completed by 1,705 students of Department of Mechanical and Electrical Engineering in Wenhua College (male 1,515, 88.86\%, female 190, $11.14 \%$ ) with an attendance rate of $99.7 \%$.

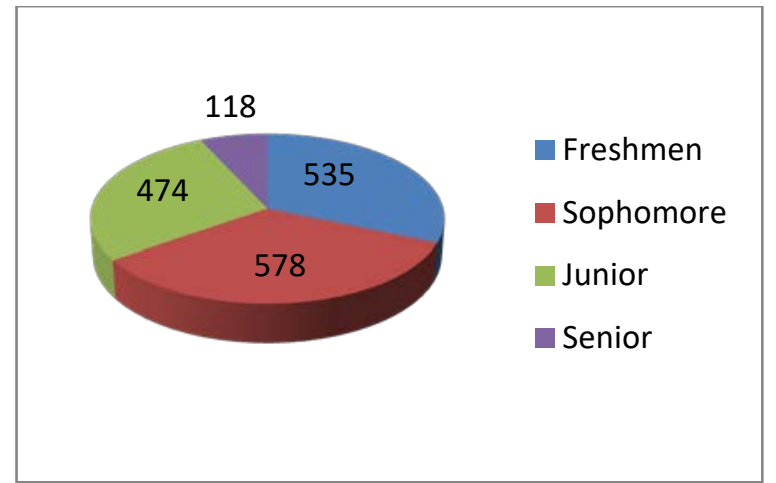

Figure 2. Students’ grade

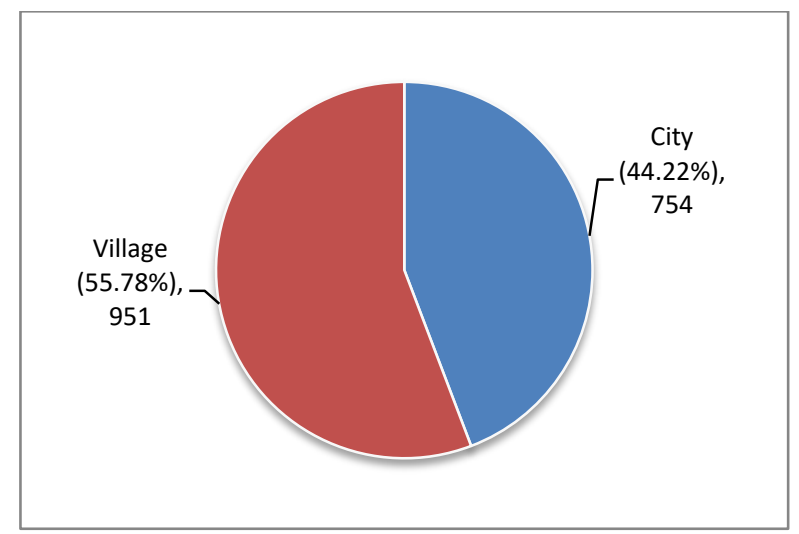

Figure 3. Students' location 
While the Spring Festival is in the winter vacation, almost all students have gone back to their hometown that is shown in Figure 3. They haven't brought computers beside because the journey usually lasts for about no more than 2 weeks. Many students went to village with only a smart phone and their network is also not so good for them to study online. Teachers must consider targeted guidance to help this group.

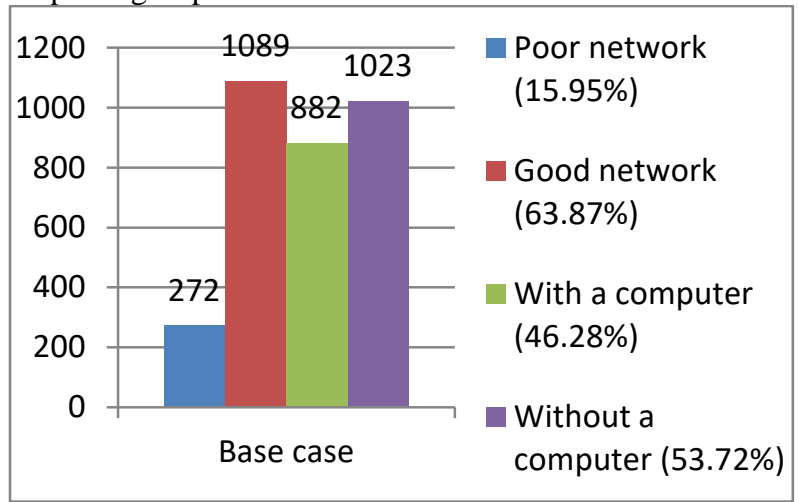

Figure 4. Students' base case for study online

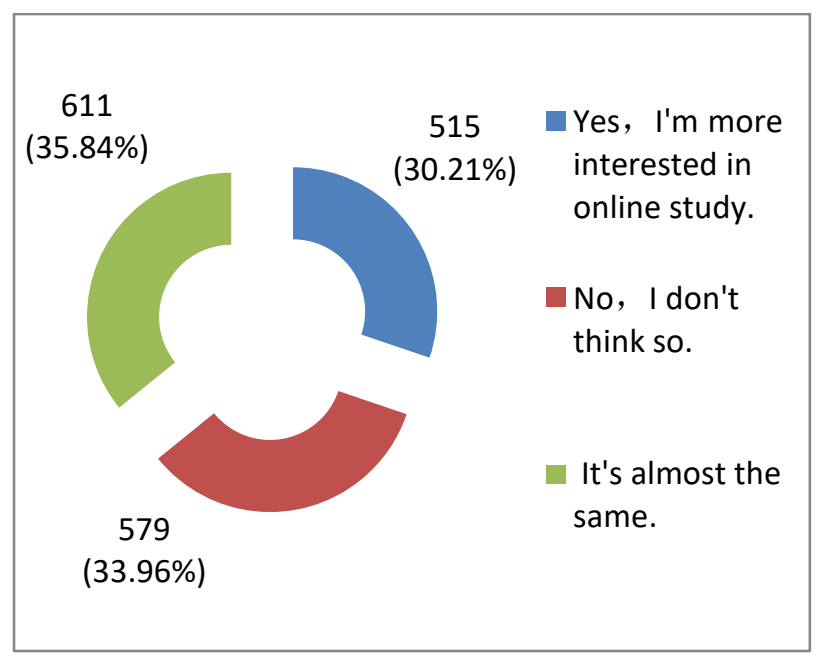

Figure 5. "Are you willing to learning autonomously more than in classroom study?”

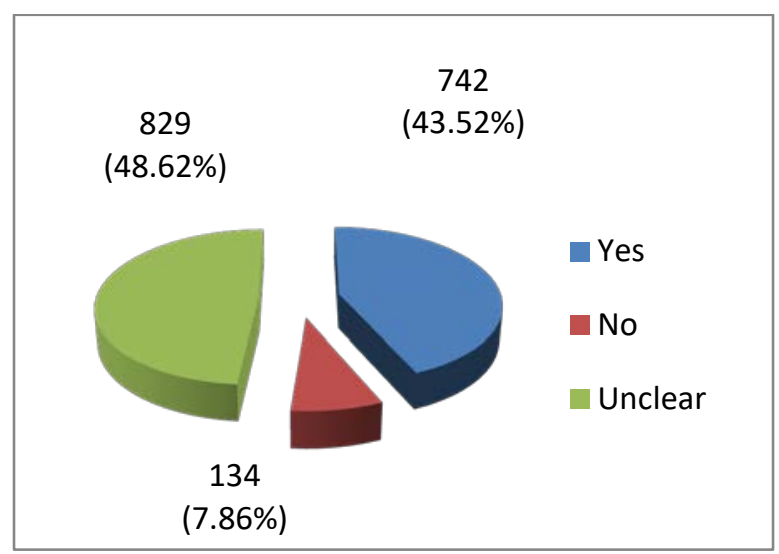

Figure 6. "Are you satisfied with the online teaching effect?"
As data are shown in Figure 5, it can be concluded that most students have at least accepted online course, which provides a guarantee for teachers to continue their teaching ways. However, although the result shows that students who are not satisfied with online course in the first month are less than one tenth of the amount as shown in Figure 6, there are still over half the students haven't obtained a very good study experience. It is highly necessary for each teacher to make effort in teaching reform and adjustment.

There are 3 main problems from the questionnaire in online course in the first month:

1. Network:

As shown in Figure 4, about one third students don't have a good network, and nationwide students from pupils to college (about 280 million) are making use of various online teaching platforms and apps. Network congestion and software crash happen inevitably everywhere, which waste so much time for both students and teachers to retry connection till the signal is stable, which happens many times in just one lesson.

2. Instruction:

In this situation, most teachers have to become a webcaster in an online platform such as Rain-Class. Teachers are forced to face their screens and operate keyboards for 90 minutes, while students should focus on PPT on the screen even someone has so small one on the smart phone that he or she might just listen to the sound. Moreover, students and teachers have little chance to look at each other and find out what they are expressing or thinking about. The course could only go ahead as teachers' expect whether students were confused if they haven't got teachers see the point.

3. Communication:

In classroom, teachers could show content directly and easily with body language. They could also learn from students' speaking and face to determine how much they have studied or which point they are puzzled about. Communications happen instantly with no delay even some students are not willing to raise a hand to speak.

But on the network, teachers could only see students by switching tiny windows in the platform from the camera if students turned it on, while they keep on speaking and operating the software. If students remain silent, teachers would never know how they feel about the class unless someone was chosen to answer a question using a mic. Furthermore, it costs too much time to do exercise in class such as to take pictures of it, send an e-mail and wait for a reply. Real-time communication seems impossible in class.

\section{REFLECTION AND REFORM IN ONLINE TEACHING}

Above all, the study is a course of interaction, renewal and self-construction. Interchange is the most important for everyone.

As shown in Figure 7, the rate of students who frequently communicate with teachers is just $8.91 \%$, and nearly one fifth students hardly call their teachers. It's extremely 
harmful to carry out education in this special period for the fact that teachers are much more difficult to learn what students feel and need as mentioned before.

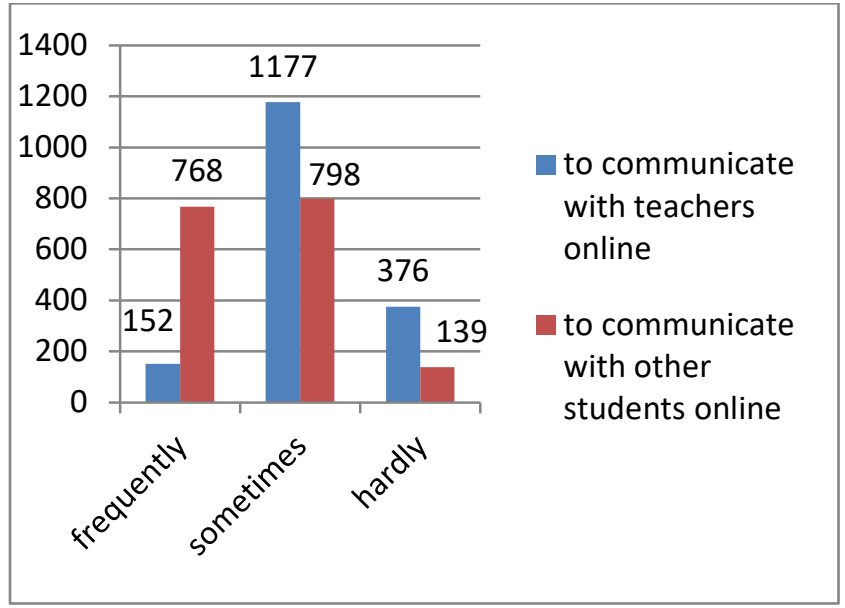

Figure 7. "Do you communicate with others?"

The good news is that only $8.15 \%$ of students hardly communicate with anyone while most students are willing to do. It creates a good learning atmosphere if teachers could stimulate students' initiative, let positive ones influence inactive ones.

According to questionnaire, about 1039 students (60.94\%) have studied more than 4 hours per day while lessons on the timetable are less than 4 hours, which shows that most students have a good learning consciousness.

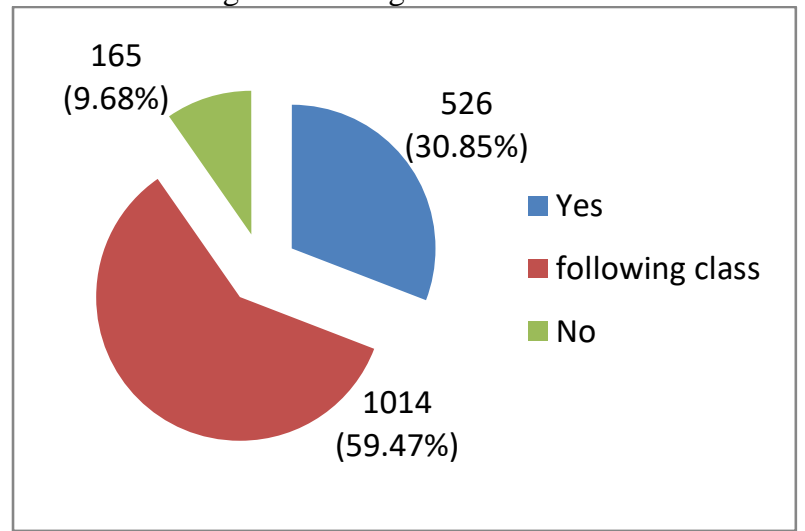

Figure 8. "Do you have detailed learning plan at home?"

As shown in Figure8, just one third students have designed a detailed learning plan. More than half of students prefer to follow the lesson as in traditional class without any preconceived plans. Students, especially in this isolation condition, highly need teachers' guidance and help.

In the post-epidemic era, teachers should learn from this experience to improve both teaching concepts and methods in the following points:

Differences: Online course is absolutely an activity with the separation of time and space between both teachers and students, which depends on network, software and digital materials. However, it doesn't mean that everyone must sit down in front of the computer all the time if they want to study. Teachers could select some targeted paper materials such as textbooks, popular science books, magazines and journals for students to read at home, which are easily to find in websites like Tmall and JD with convenient express delivery in China. It is advised that students study online for no more than 4 hours per day.

Changes: Teaching online as a webcast is not a very good way in most cases but the most suitable way that everyone could accept in this situation. It is necessary for teachers to reconstruct their teaching model, process and method in order to improve the effect. Online course is essentially a students' self-learning with guidance. Teachers should do their best to create a good environment and conditions for students.

1. To attract students' to stay focused in class.

Attraction: infectious speaking, concise text, representative figures, oriented and challenging questions.

Pressure: planned panel discussion, requirement and check. 2. Suitable materials after class.

Interesting short videos, typical examples, books, recorded broadcast and other selected resources.

3. Q\&A in real-time.

Specific time in the Rain-Class platform that student each airs his own views.

4. Guidance.

Help students to form self-direction and self-learning to ensure the success of individualized education.

5. PBL course design

Project-based learning for small classes.

Problem-based learning for large classes.

\section{CONCLUSION}

It is a convenient communication channel that online education requires a basic and important condition. The more teachers have prepared for, the less requirement on software and platform. One of the primary goals of an educator should be to help students develop the desire and ability to think on their own. It is teachers' next main aim to work out a custom learning program and individual guidance for each student, with global education resources over the internet. Our present work is a part of what's going to happen in future education.

\section{REFERENCES}

[1] Zhentian LIU, Qiang LIU, How Online Teaching Can Help College Classroom Revolution Understanding Large-Scale Online Teaching Under Epidemic Situation, Journal of East China normal university (Educational Sciences), 2020, No.7, pp. 31-41.

DOI:https://10.16382/j.cnki.1000-5560.2020.07.002. (In Chinese)

[2] Yingying LI, Hongmei ZHANG, Haizhou ZHANG, Model Construction and Empirical Test of College Students'Satisfaction with Online Learning During 
Epidemic Prevention and Control Period Based on the Survey of 15 Universities in Shanghai, Open Education Research, 26(4) (2020), 102-111.

DOI:https://10.13966/j.cnki.kfjyyj.2020.04.012. (In Chinese)

[3] Chenglong XUE, Yingxia GUO, Reflections and Recommendations on the Reform of Online Teaching Reform in Universities, Journal of East China Normal University (Educational Sciences), 2020, No.7, pp. 6574. DOI: https://10.16382/j.cnki.10005560.2020.07.005. (In Chinese)

[4] Meixuan LI, Exploration and Research of Online Teaching Based on COVID-19 Epidemic, Journal of Liaoning Higher Vocational, 22(8) (2020), 11-16, 35. DOI: https://1009-7600 (2020)08-0011-06. (In Chinese)

[5] Daguang WU, Wen LI, Stage Characteristics of Large-Scale Online Teaching In Chinese Universities: Empirical Research Based on Group Investigation of Students, Faculty and Academic Staff, Journal of East China normal university (Educational Sciences), 2020,
No.7, pp. 1-30. DOI: https://10.16382/j.cnki.10005560.2020.07.001. (In Chinese)

[6] Deyu Tang, Innovative Research on the Mixed Teaching Mode of Bioinformatics After the Epidemic, Computer and Information Technology, 28(4) (2020), 67-69. DOI: https://10.19414/j.cnki.1005-1228.2020.04. 021. (In Chinese)

[7] Rhinehart N, Kitani K M, First-Person Activity Forecasting from Video with Online Inverse Reinforcement Learning, IEEE Transactions on Pattern Analysis and Machine Intelligence, 42(2) (2020), 304317. DOI: https://10.1109/TPAMI.2018.2873794.

[8] Sincak C, Gunn J, Conroy C, et al, Transformation of an Online Multidisciplinary Course into a Live Interprofessional Experience, American journal of pharmaceutical education, 2017, pp. 81-94. DOI:https://10.5688/ajpe81594. 